\title{
An Norovirus Outbreak at a Local Festival in Chungnam Korea
}

\author{
Hyunah Lee ${ }^{1,2}$, Donguk Kim¹, Seongmin Park' ${ }^{1}$ Jongjin Park ${ }^{1}$, Hae-Sung Nam ${ }^{3}$, Jinha Choi' and Junhyuk Park ${ }^{1 *}$ \\ ${ }^{1}$ Department of Health Research, Chungcheongnam-Do Institute of Health and Environment Research, \\ Hongseong, Korea \\ 2Department of Public Health, Chungnam National University Graduate School, Daejeon, Korea \\ ${ }^{3}$ Department of Preventive Medicine and Public Health, Chungnam National University, Daejeon, Korea
}

\author{
Corresponding \\ Junhyuk Park \\ Chungcheongnam-Do Institute of Health and \\ Environment Research, 8 Hongyegongwon-ro, \\ Hongbuk-myeon, Hongseong, 32254, Korea \\ Phone : +82-41-635-6832 \\ Fax : +82-41-635-7942 \\ E-mail : park.jun.hyuk.2019@gmail.com
}

Received : February 28, 2019

Revised : May 8, 2019

Accepted : May 8, 2019
No potential conflict of interest relevant to this article was reported.

Copyright (C) 2019 Journal of Bacteriology and Virology

(C) This is an Open Access article distributed under the terms of the Creative Commons Attribution Non-Commercial License (http://creativecommons.org/ license/by-nc/3.0/)
Noroviruses (NoV) are the major viral pathogen causing epidemic acute gastroenteritis and outbreaks of foodborne and waterborne illness. During the local festival in Chungnam province, group food poisoning occurred outbreak by NoV infections in Jan 2019. In this study, epidemiological analysis and molecular characterization were conducted such as genotyping, phylogeny. The prevalent genotypes of food poisoning events were NoV GII.3 and GII.17, and NoV GII.3 and GII.17 isolates of this study were completely matched in nucleotide sequence comparison of capsid gene region, respectively. In underground water and stream water, various multiple genotypes of noroviruses were detected including NoV GII.3, GII.8 and GI.4 in aquatic environment of the local festival site. Among 32 worker samples, various NoVs of five genotypes (GI.7, GI.8, GII.3, GII.8, GII.17) were detected in 12 samples and expected to causing NoV contaminated by exposure to groundwater. NoV genotype GII.3, which was detected from groundwater 2, was completely consistent with that of patients and workers. Therefore, groundwater within the local festival site could be main cause of food poisoning event. Because NoV outbreaks are caused by fecal to oral transmission, proper management of sewage purification facilities, groundwater and sanitary toilets is required for many visitors, and efforts are needed to maintain clean environment.

Key Words: norovirus outbreak, group food poisoning, groundwater contamination

\section{INTRODUCTION}

전 세계적으로 노로바이러스는 전 연령대에 걸쳐 급성 바이러스성 장염을 일으키는 중요한 원인 병원체이며, 집단으로 발생하는 바이러스성 식중독 중 $90 \%$ 이상을 차 지한다 (1). 노로바이러스는 Zahorsky 등에 의해 1929년에 "겨울철 구토질환"으로 처음 보고되었고, 1972년 Kapikian 등이 면역전자현미경으로 확인하였다 (2). 노로바 이러스의 전파는 분변-구강 또는 구토에 의한 비말형성에 의하여 주로 일어나며, 일 반적으로 12 2월 사이의 겨울철에 유행한다. 주 증상은 구토나 설사 또는 두 증상 이 동시에 나타나고, 24 48시간의 잠복기를 거친 후에 증상이 발현되어 하루에서 이틀 동안 지속된다. 증상이 있는 동안에 환자가 무기력해 질 수 있으나 일반적으로 경미한 증상을 보이며 드물게 심한 증상을 보이기도 한다 (3). 노로바이러스는 항원 이 매우 다양하여 한 가지 유전자형에 감염 되는 경우에도 다른 형에 의한 재 감염이 일어나기도 하며, 면역력은 평생 지속되지 않으며 반복적인 노출에 의한 재감염이 일어나기도 한다 (4). 이 바이러스는 Caliciviridae에 속하며, $7.5 \mathrm{~kb}$ 의 단일가닥 RNA 바이러스로서 유전자는 세 개의 단백질을 코딩하고 있다. 바이러스의 캡시드 유전자 와 중합효소유전자 염기서열의 다양성을 기반으로 6 개의 유전자그룹(G)으로 나뉘며, 
그 속에는 최소 38개의 유전자형으로 세분화되어 있으며 (5 7), 이들 중 사람에게 주로 문제를 일으키는 유전자그룹은G I, GII, GIV 이다 $(5,8)$. 노로바이러스는 먹는 물과 식품을 매개로 전파되어 집단발병을 일으키는 중요한 병원체인데, 이들 집단에서 순환 되는 노로바이러스의 전파를 이해하기 위해서는 유전자 염기서열을 분석하여 유전자형을 결정하는 것이 효과적이다 (6). 노로바이 러스는 18 1,000개의 입자로 감염을 유발할 수 있고, 유전적 다양성이 매우 높으며, 다양한 환경 스트레스로부터 높은 저항성 을 갖기 때문에 군집 내에서 쉽게 퍼져나갈 수 있다 (9). 특히, 하수, 강물, 바닷물과 지하수 등 다양한 수계 환경접촉에 의하여도 노로바이러스가 광범위하고 빠르게 전파가 가능하다 (10). 본 연구는 충청남도 내 지역 축제에서 발생한 노로바이러스 집단 감염 에 대하여 환자 29 명과 종사자 32 명 그리고 8 건의 환경 검체에서 노로바이러스 검사를 실시하고 검출된 바이러스의 유전자형 결 정 및 분자 생물학적 특성 규명하는 것으로 역학적인 분석을 실시하였고, 이를 보고함으로써 앞으로 이와 유사한 집단식중독에 대한 효율적인 예방자료로 사용하고자 한다.

\section{MATERIALS AND METHODS}

\section{검체 및 전처리}

2019년 1월 충남 지역 축제 중 겨울 스포츠 단체 체험 후 구토 및 설사증상을 보이는 $A$ 지역 초등학생 및 부설유치원생 15명, B 지역 어린이집 아동 및 교사 14 명, 지역축제 관련 시설종사자 32 명, 지하수 4 건, 하천수 2 건, 칼과 도마 각 1 건에 대한 노로바이 러스 검사를 실시하였다.

\section{인체 검체}

인체 검체는 직장면봉으로 채취한 후 멸균된 $0.1 \mathrm{M}$ phosphate buffered saline (PBS, Sigma, St. Louis, MO, USA) 3 mL에 넣어 진탕하고, $3,000 \mathrm{RPM}$ 에서 10 분간 원심 분리하여 상청액을 얻어, 검출시험에 사용할 때까지 $-70^{\circ} \mathrm{C}$ 에 보관하였다.

\section{환경 검체}

지하수는 지역 축제장 내 관정 2 곳, 식당의 수도꼭지수 1 곳, 장외 관정 1 곳, 그리고 하천수는 인접 하천 두 곳에서 채취하였다. 지하수의 경우, Liquid Filtration System (1MDS-2000, 3M, Korea)에 Nano Ceram 필터(VS2.5-5, Argonide corporation, Sanford, FL, USA)를 장착하고 1,500 1,800 L의 지하수를 통과시켜 바이러스를 흡착하였고, 하천수는 $4 \mathrm{~L}$ 채수병 3 개씩 채수하 여 직접 필터를 통과시켜 바이러스를 흡착시켰다. 바이러스가 흡착된 필터는 바로 표준 처리방법에 준하여 탈리 및 농축을 실시

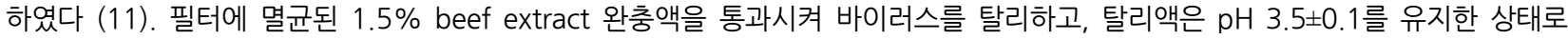
실온에서 30 분간 천천히 교반하였다. 침전물이 생기면 $4^{\circ} \mathrm{C}$ 에서 $2,500 \times \mathrm{g}$ 로 15 분간 원심분리 후에 상층액을 제거하여 침전물에 $0.15 \mathrm{M}$ sodium phosphate 완충액을 넣어 부유시키고, 실온에서 10 분간 방치하였다. 부유액은 $4^{\circ} \mathrm{C}$ 에서 $7,000 \times \mathrm{g}$ 로 10 분간 다 시 원심분리 하고 $\mathrm{pH}$ 를 7.0 0.2 로 조절하였다. 세균 오염을 방지하기 위해 $50 \mathrm{~mL}$ 주사기에 $0.22 \mu \mathrm{M}$ 멸균필터를 부착하여 상층 액을 여과, 최종 농축 검체 $20 \mathrm{~mL}$ 를 유전자 추출을 위한 검체로 사용하였다. 다만, 사전에 $20 \mathrm{~mL}$ 의 $1.5 \%$ beef extract 완충액을 멸균 필터에 통화시켜 검액 중의 바이러스가 필터에 흡착하는 것을 방지하였다. 또한 식당에서 사용한 칼과 도마는 멸균된 면봉 으로 2개씩 무균상태에서 도말하였고, 멸균된 $0.1 \mathrm{M} \mathrm{PBS} 3 \mathrm{~mL}$ 에 넣어 충분히 진탕하였고, 시험에 사용될 때까지 $-70^{\circ} \mathrm{c}$ 에서 보관 하였다.

\section{노로바이러스 진단}

노로바이러스는 real time RT-PCR법을 이용하여 검사하였다. 전 처리된 인체검체와 지하수 검체 $200 \mu \mathrm{L}$ 를 취하여 핵산추출장비 (Nextractor, Genolution, Korea)와 추출키트(NX-48 Viral NA kit, Genolution, Korea)를 이용하여 제조사의 사용방법에 따라 RNA를 추출하였다. 추출된 RNA는 PowerChek ${ }^{\text {TM }}$ Norovirus GI/GIl Multiplex Real-time PCR kit (Kogenebiotech, Korea)를 이 용하여 진단하였다. 추출된 RNA $5 \mu \mathrm{L}$ 를 각각의 키트에 첨가 하였는데, 특히 지하수에서 추출된 것은 각 RNA 당 3 개씩 중복하여 시험하였다. 반응조건은 $50^{\circ} \mathrm{C} 30$ 분 1 회, $95^{\circ} \mathrm{C} 10$ 분 1 회, $95^{\circ} \mathrm{C} 15$ 초, $55^{\circ} \mathrm{C}$ 1분 동안 45 회 반복하여 real-time PCR(AB7500 Fast, Thermo Fisher Scientific, Waltham, MA, USA)에서 반응하였다. 결과는 threshold 0.2일때, Ct (Threshold Cycle)값이 36이하인 것을 양성으로 판단하였다. 


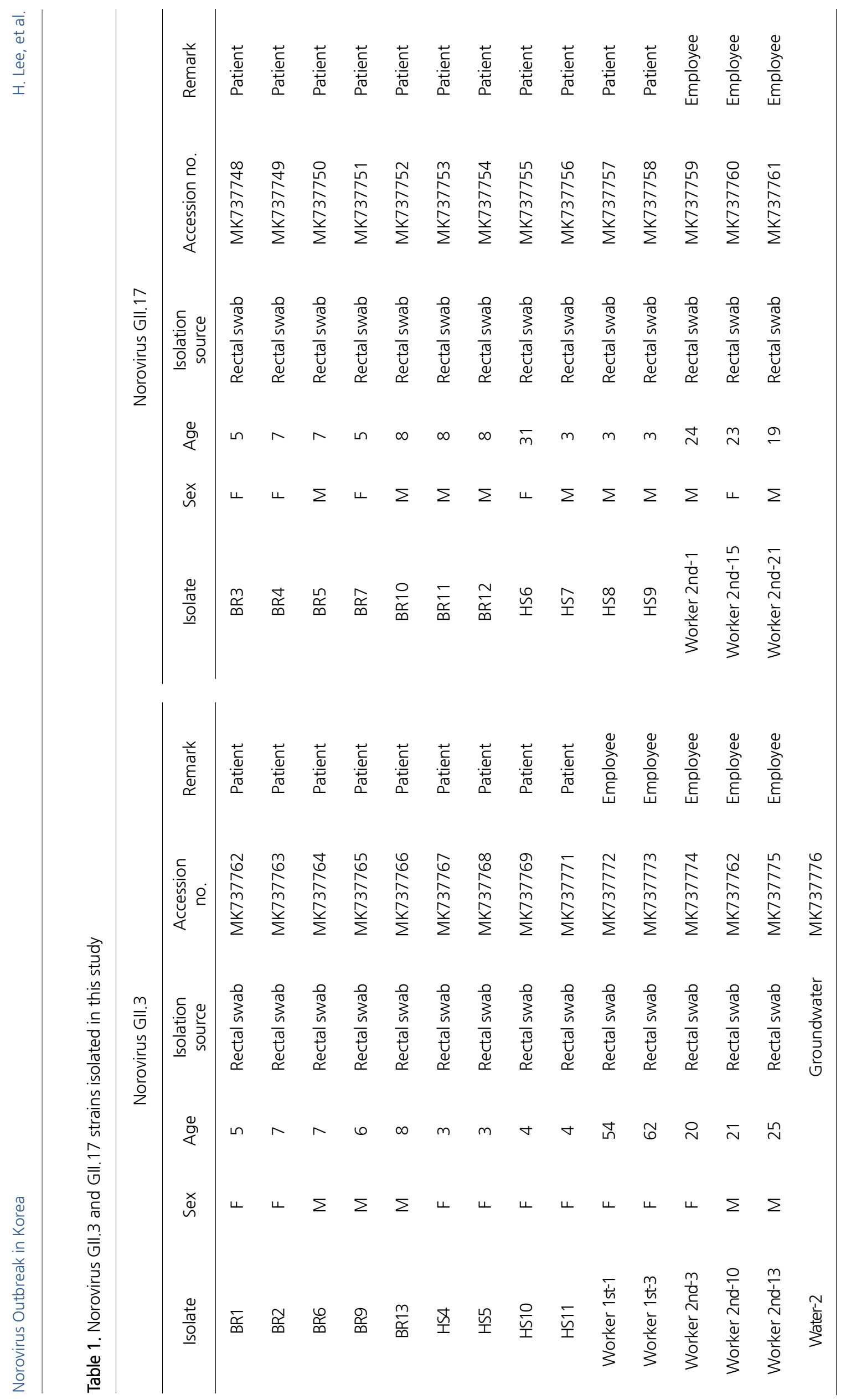




\section{노로바이러스 유전자형 결정 및 계통분석}

\section{Reverse transcription-polymerase chain reaction (RT-PCR)}

양성으로 판정된 노로바이러스는 유전자형 분석을 위하여 semi-nested RT-PCR법을 이용하여 캡시드 유전자는 증폭하였다. 추출 된 RNA는 Access RT-PCR system (Promega, USA)과 노로바이러스에 특이적인 프라이머를 이용하여 실험하였다 $(8,12)$. 노로바 이러스GI 프라이머는 GI-F1M (5'-CTGCCCGAATTYGTAAATGATGAT-3')과 GI-R1M (5'-CCAACCCARCCATTRTACATYTG-3')이 고, 노로바이러스 GII 프라이머는GII-F1M (5'-GGGAGGGCGATCGCAATCT-3') 과 GIII-R1M (5'-CCRCCIGCATRICCRTRTACAT-3') 을 사용하였다. RNA $5 \mu \mathrm{L}$ 를 각각의 키트에 추가 시킨 후 $47^{\circ} \mathrm{C}$ 에서 40 분간 CDNA를 합성하고, $94^{\circ} \mathrm{C} 30$ 초, $54^{\circ} \mathrm{C} 30$ 초, $72^{\circ} \mathrm{C} 455^{\circ}$ 동안 35회 반복하여 PCR 반응을 수행하였다. 그 후 1차 반응산물 $2 \mu \mathrm{L}$ 를 취하여 PCR system (Promega, Madison, WI, USA)을 이용하여 semi-nested PCR을 수행하였다. 노로바이러스 GI프라이머는GI-F2 (5'-ATGATGGCGTCTAAGGACGC-3')과 GI-R1M,

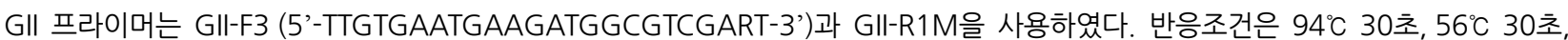
$72^{\circ} \mathrm{C} 45$ 초 동안 25회 반복하였다. PCR 증폭에 의해 생성된 QIAxcel (QIAgen, Valencia, CA, USA)을 이용하여 전기영동 한 후 $\mathrm{Gl}$ 은 $330 \mathrm{bp}, \mathrm{Gll}$ 는 $332 \mathrm{bp}$ 의 밴드를 확인하였다.

\section{노로바이러스의 유전자형 결정 및 계통분석}

유전자형 결정을 위한 유전자 염기서열은Genotech (Korea)에 의뢰하여 분석하였고, 분석된 각 염기서열은 Editseq (DNAStat, Madison, WI, USA)에서 편집한 후, National Center for Biotechnology Information (NCBI)의 Basic Local Alignment Search Tool (BLAST)을 통하여 이루어졌다. 이 중 GII.3형과 GII.17형에 대한 염기서열은 NCBI의 Genbank에 MK737749 MK737776 으로 등록하였다 (Table 1). 이들을 이용하여 최근 집단발생에 분리된 노로바이러스들과 각 유전자형의 국외참조주들과 함께 계통 분석을 실시하였다. Clustal-X (European Molecular Biology Laboratory, https://www.embl.org/)를 이용하여 다중정렬을 수행한 후, 정렬된 자료는 Molecular Evolutionary Genetics Analysis (MEGA, https://www.megasoftware.net/) 프로그램을 이용하여 계통분석을 실시하였다 $(13,14)$

\section{RESULTS}

2019년 1월 중 충청남도 내 지역축제에서 겨울스포츠를 단체 체험한 "A"지역의 돌봄 교실 아이들과, "B"지역의 어린이집 아이들 에서 집단적으로 구토 및 설사 증세를 보이는 환자들이 발생하였다. 전체적으로 두 시군 101 명이 지역 축제장 내 동일한 식당에 서 점심식사와 음용수를 섭취한 것으로 확인되었고, 이 중 38 명(37.6\%)에서 33 41시간 이후에 구토, 설사 및 복통 등의 증상 을 호소하였다 (Table 2).

Table 2. Exposed persons and patients with symptoms for norovirus infection

\begin{tabular}{cccc}
\hline & $\begin{array}{c}\text { No. of } \\
\text { exposed persons }\end{array}$ & $\begin{array}{c}\text { No. of illness } \\
\text { (incidence rate) }\end{array}$ & $\begin{array}{c}\text { Time from exposure to } \\
\text { onset of symptoms }\end{array}$ \\
\hline $\begin{array}{c}\text { Children at an elementary } \\
\text { school in "A" city }\end{array}$ & 33 & $\begin{array}{c}15 \\
(45.4 \%)\end{array}$ & 33 hr after lunch \\
$\begin{array}{c}\text { Children at a nursery in "B" } \\
\text { county }\end{array}$ & 68 & $\begin{array}{c}23 \\
(33.8 \%)\end{array}$ & 41 hr after lunch \\
\hline
\end{tabular}

노로바이러스 검사를 실시한 환자는 29 명이었고, 22 명에서 노로바이러스 $\mathrm{Gll}$ 가 검출되어 약 $75.9 \%$ 의 양성율을 보였다. 구체적인 유전자형은 GII.2형 1명, GII.3형 9명 그리고 GII.17형이 12명이었다 (Table 3). 
Table 3. Detection and distribution of genotypes of noroviruses in fecal samples of patients

\begin{tabular}{ccccccc}
\hline & $\begin{array}{c}\text { No. of } \\
\text { samples }\end{array}$ & $\begin{array}{c}\text { norovirus positive samples } \\
\text { (positive rate) }\end{array}$ & Gll.2 & Gll.3 & Gll.17 & Total \\
\cline { 4 - 7 } & 15 & 13 & 0 & 5 & 8 & 13 \\
$\begin{array}{c}\text { Children at an elementary } \\
\text { school in "A" city }\end{array}$ & & $(86.6 \%)$ & $(0.0 \%)$ & $(38.5 \%)$ & $(61.5 \%)$ & $(100 \%)$ \\
$\begin{array}{c}\text { Children at a nursery in } \\
\text { "B" county }\end{array}$ & 14 & 9 & 1 & 4 & 4 & 9 \\
\end{tabular}

지역 축제장에서 근무하는 시설종사자 32 명에 대한 검사를 실시한 결과, 12 명에서 노로바이러스가 검출되어 $37.5 \%$ 의 양성율을 보이고 있었다. 이 중 한 명은 중복감염으로 검출된 바이러스는 13건이었으며, 세부적으로는 Gl.7형 1건, Gl.8형 3건, Gll.3형 5건, Gll.8형 1건, 그리고 Gll.17형이 3건이었다 (Table 4).

Table 4. Detection and genotype distribution of noroviruses in fecal samples of food-service employees

\begin{tabular}{ccccccccc}
\hline & $\begin{array}{c}\text { No. of } \\
\text { samples }\end{array}$ & $\begin{array}{c}\text { No. of norovirus- } \\
\text { positive samples } \\
\text { (positive rate) }\end{array}$ & Gl.7 & Gl.8 & Gll.3 & Gll.8 & Gll.17 & Total \\
\hline $\begin{array}{c}\text { Food-service } \\
\text { employees }\end{array}$ & 32 & $\begin{array}{c}12 \\
(37.5 \%)\end{array}$ & $\begin{array}{c}1 \\
(7.7 \%)\end{array}$ & $\begin{array}{c}3 \\
(23.1 \%)\end{array}$ & $\begin{array}{c}5 \\
(38.5 \%)\end{array}$ & $\begin{array}{c}1 \\
(7.7 \%)\end{array}$ & $\begin{array}{c}3 \\
(23.1 \%)\end{array}$ & $\begin{array}{c}13 \\
(100 \%)\end{array}$ \\
\hline
\end{tabular}

환경시료는 환자들이 점심식사를 하였던 식당에서 사용되고 있는 칼과 도마에서 각각 도말하여 채취하였고, Groundwater-1은 식 당 안의 수도꼭지에서 나오는 지하수를 채수하였고, 나머지 3건은 지역축제장 내 관정 2곳과 축제장 외 관정 1곳 에서 채수 하였 다. 그 결과 2건의 노로바이러스가 검출되었는데, 이들의 유전자형은 각각 GII.3형과 GII.8형이었으며, 부가적으로 실시한 “먹는물 수질기준”에 따른 검사 결과 Groundwater 1번에서 총대장균군과 분원성대장균이 검출되었다. 행사장 내부를 거쳐 흐르는 하천 수 두 곳을 선정하여 12 L에서 노로바이러스 검사를 수행한 결과, 그 중 한 곳에서 노로바이러스 GI.4형이 검출되었다. 이로써 지 하수 및 하천수 6 개소 중 절반에 해당하는 3 개소에서 각기 다른 유전자형의 노로바이러스가 검출됨을 확인할 수 있었다 (Table 5).

Table 5. Detection and genotype distribution of noroviruses for groundwater, stream water and kitchen utensils

\begin{tabular}{cccc}
\hline Specimens & Detection of norovirus & Genotype & Remark \\
\hline Groundwater-1 & Positive & Gll.8 & Positive for \\
Groundwater-2 & Positive & - & total coliforms and fecal coliforms \\
Groundwater-3 & Negative & - & - \\
Groundwater-4 & Negative & Gl.4 \\
Stream water-1 & Negative & - & \\
Stream water-2 & Positive & & \\
Swab with knife & Negative & - \\
used in the restaurant & Nwab with cutting board & & \\
used in the restaurant & & &
\end{tabular}

환자 대부분에서 검출된 노로바이러스 GII.3형과 GII.17형에 대해서 다중정렬을 실시하였고, 이를 바탕으로 계통분석을 수행하였 다. 본 집단 식중독에서 검출된 노로바이러스 GII.3형의 경우, 환자와 종사자 그리고 지하수에서 모두 검출되었는데, 분석결과 이 들에서 검출된 노로바이러스들은 캡시드 부분 유전자 염기서열 $254 \mathrm{bp}$ 에서 $100 \%$ 일치하여 유행을 주도한 노로바이러스가 동일 한 분리주임이 확인되었다 (Fig.1). 2018년 국내의 다른 지역에서 집단발병의 원인이 되었던 노로바이러스 GII.3형과는 98.4 
$98.8 \%$ 의 상동성을 보이고 있었고, 미국의 분리주들 CHD4031, CHDC2005, CHDC5261과는 90.9 93.7\%의 상동성을 보이고 있었다.

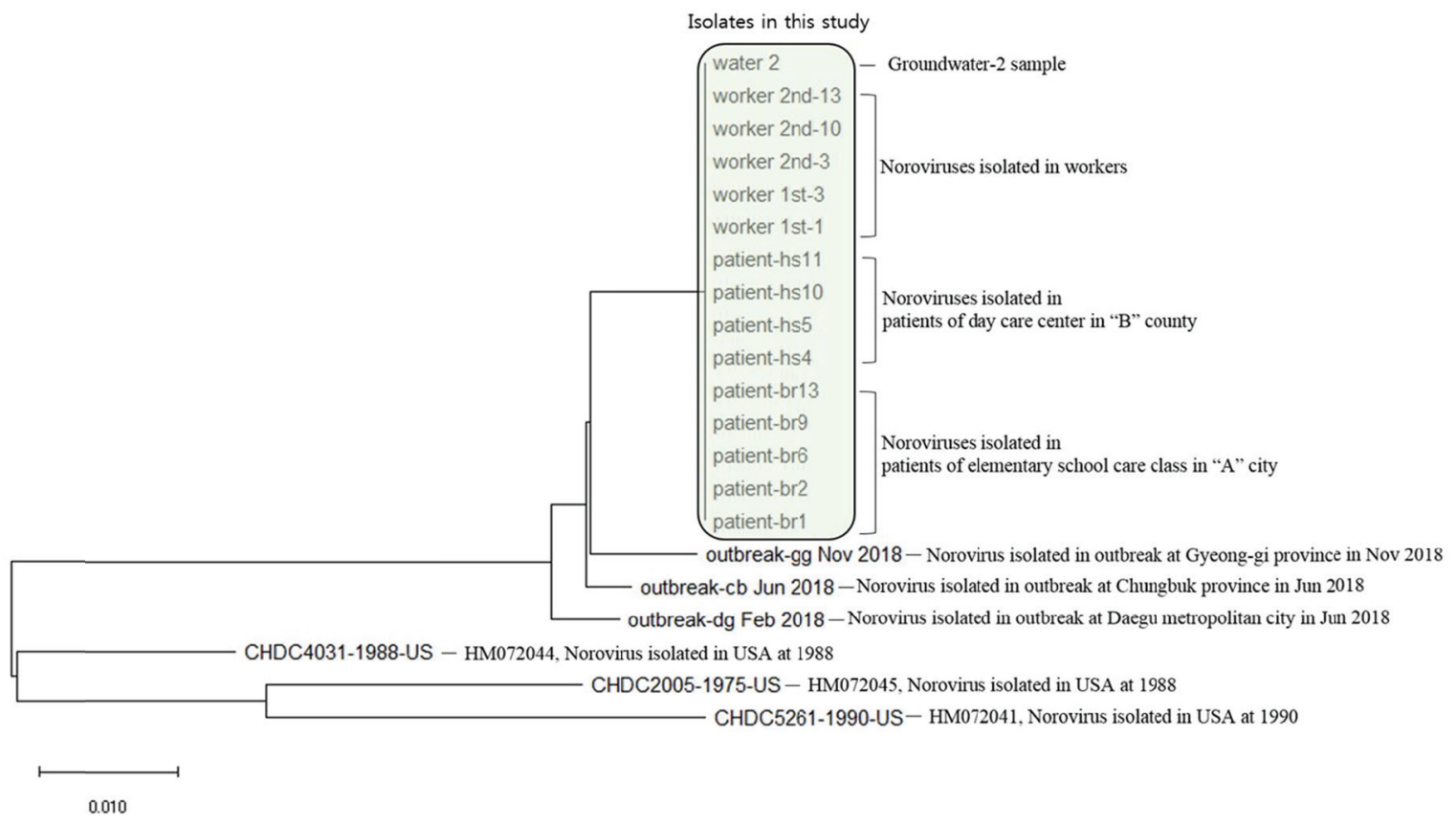

Figure 1. Phylogenetic analysis of isolates in this study with reference strains for 254bp of capsid gene of norovirus GIl.3

본 집단 식중독에서 검출된 노로바이러스 GII.17형의 경우, 환자와 종사자에서 검출되었는데, 분석결과 이들에서 검출된 노로바 이러스의 캡시드 부분 유전자 염기서열 $255 \mathrm{bp}$ 에서 $100 \%$ 일치하여 환자와 종사자에서 유행한 노로바이러스가 동일한 분리주임 이 확인되었다 (Fig.2). 2019년 국내의 다른 지역에서 집단발병의 원인이 되었던 노로바이러스 GII.3형과는 99.6 100\%의 상동 성을 보이고 있었다. 1978년 프랑스령 기아나에서 분리된 GII.17형과 85.9\%의 상동성을 보였으며, 2005년 미국에서 분리된 "Katrina17"주와는 $96.9 \%$ 의 상동성을 보이고 있었다.

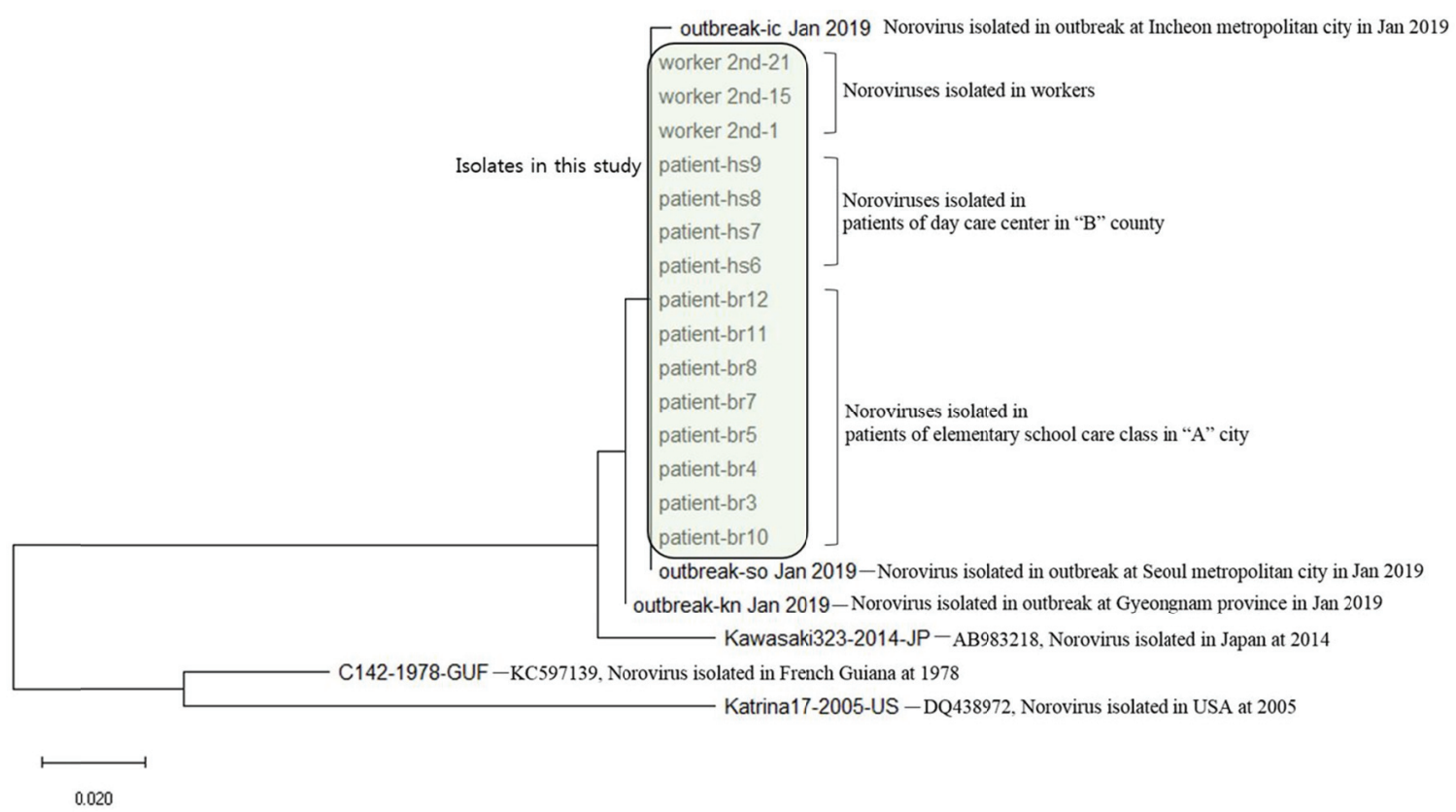

Figure 2. Phylogenetic analysis of isolates in this study with reference strains 255bp of capsid gene of for norovirus GII. 17 


\section{DISCUSSION}

노로바이러스는 바이러스성 설사 질환의 주요한 병원체로 전체 바이러스성 설사의 약 $10 \%$ 를 차지하고 있고, 특히 집단으로 발생 하는 바이러스성 식중독의 대부분 원인으로 보고되고 있다 (1). 산발적인 노로바이러스 감염에 대한 발생이 겨울철에 유행하는 것 과는 달리 집단발병의 경우 국내외에서 계절적 특성과 상관없이 발생하는 비전형적인 사례들이 보고되고 있다 $(15,16)$. 또한 노 로바이러스는 환경적 요인에 저항성이 매우 큰 바이러스로 높은 감염성과 광범위한 전염력을 보인다. 특히 물을 매개로 대단위로 전파되는 특징을 보이며, $27 \mathrm{~nm}$ 의 크기로 매우 작아서 토양침투가 용이하고 저온이 유지되는 지하수에서는 장기간 생존이 가능하 다 $(10,17,18)$. 본 연구는 2019년 1월 충청남도 내 지역행사에서 발생한 노로바이러스에 의한 집단 식중독에 대한 분자 역학적 분석을 실시하여 이를 보고하고자 하였다. 본 지역축제에서 발생한 집단식중독의 원인은 노로바이러스로, 유전형은 GII.3형과 GII.17형 두 가지 유전자형의 바이러스가 식중독을 주도한 것으로 판단되는데, 분석된 캡시드 유전자 부위의 염기서열이 $100 \%$ 일치하여 각 유전자형의 동일 바이러스가 유행을 일으킨 것으로 생각된다. 환자 1명에서 검출된 GII.2형의 경우, 시기적으로 추가 로 채취되어 의뢰된 경우로써, 본 집단식중독과 상관없이 외부에서 감염되어 유입되었을 가능성이 존재한다. 지하수와 하천수 총 6건 중 3건에서 GII.8형과 GII.3형 그리고 GI.4형이 검출되어 지역축제장내 수계 환경에서 여러 유전자형의 노로바이러스가 존재 하고 있음을 알 수 있었고, Groundwater-3에서 분리된 GII.3형은 환자와 종사자에서 분리된 것과 유전자 서열이 $100 \%$ 일치하 여 지하수가 식중독 발생 주요 원인임이 증명되었다. 그러나, 환자 또는 종사자에서 검출되었으나, 지하수에서 검출되지 않은 GII.2형과 GII.17형의 경우 환경에서 바이러스 검출법의 민감도나 회수율의 한계에 따라 검출되지 않았을 가능성과 외부에서 유입 등 다른 원인에 의해서 유행하였을 가능성이 존재한다. 이들에 대한 보다 정확한 규명을 위하여 식당에서 사용된 식재료의 오염 여부 및 식당내부로 유입되는 지하수에 대한 추가적인 검사가 필요할 수 있다. 종사자 32 명 중 12 명 $37.5 \%)$ 에서 5 개의 유전자 형 $(\mathrm{Gl} .7, \mathrm{Gl} .8, \mathrm{G} l 1.3, \mathrm{G} \| 1.8, \mathrm{Gll} .17)$ 이 검출된 것은 종사자들이 오염된 지하수에 접촉되었음이 예상되며, 이로써 종사자로 접근하기 보다는 본 식중독의 원인으로 생각되는 지하수에 지속적으로 노출된 노출자로 보는 것이 타당해 보인다. 그리고 "먹는물 수질기준" 에 따른 검사결과 총대장균군과 분원성 대장균이 검출된 것은 지하수에 분변 유입 가능성을 보이며, 노로바이러스가 포함된 분변 일 확률이 높은 것으로 판단된다. 노로바이러스는 숙주인 사람에 감염된 후 증식하여 분변을 통해 배출되므로, 많은 시설이용객에 적정한 오수 정화시설과 위생적인 화장실 등의 관리가 필요하다. 축제장내 환경을 둘러본 결과, 관정 위치가 외부하천의 흐름 및 화장실 등과 인접되어 있는 문제를 가지고 있었는데, 지표수의 유입이 우려되어 관정 및 상.하수관로 등에 대한 점검과 깨끗한 환 경유지를 위한 노력이 요구된다. 또한 축제장내 종사자들의 높은 감염률로 보아 종사자들에 대한 주기적인 위생교육과 철저한 개 인 위생관리가 필요하다. 추가적으로 행사장의 눈, 얼음 조각 등에 사용되는 하천수의 오염도검사 등이 선행되어야 할 것으로 생 각된다.

\section{REFERENCES}

1) Lee RM, Lessler J, Lee RA, Rudolph KE, Reich NG, Perl TM, et al. Incubation periods of viral gastroenteritis: a systematic review. BMC Infect Dis 2013;13:446.

2) Kapikian AZ, Wyatt RG, Dolin R, Thornhill TS, Kalica AR, Chanock RM. Visualization by immune electron microscopy of a 27-nm particle associated with acute infectious nonbacterial gastroenteritis. J Virol 1972:10:1075-81.

3) Kaplan JE, Gary GW, Baron RC, Singh N, Schonberger LB, Feldman R, et al. Epidemiology of Norwalk gastroenteritis and the role of Norwalk virus in outbreaks of acute nonbacterial gastroenteritis. Ann Intern Med 1982;96:756-61.

4) Gallimore Cl, Cubitt D, du Plessis N, Gray JJ. Asymptomatic and symptomatic excretion of noroviruses during a hospital outbreak of gastroenteritis. J Clin Microbiol 2004;42:2271-4.

5) Vinjé J, Hamidjaja RA, Sobsey MD. Development and application of a capsid VP1 (region D) based reverse transcription PCR assay for genotyping of genogroup I and II noroviruses. J Virol Methods 2004;116:109-17.

6) Bruggink LD, Dunbar NL, Catton MG, Marshall JA. Norovirus genotype diversity associated with gastroenteritis outbreaks in Victoria in 2013. Commun Dis Intell Q Rep 2015;39:E34-41. 
7) Rahman M, Rahman R, Nahar S, Hossain S, Ahmed S, Golam Faruque AS, et al. Norovirus diarrhea in Bangladesh, 2010-2014: prevalence, clinical features, and genotypes. J Med Virol 2016:88:1742-50.

8) Kim MS, Koo ES, Choi YS, Kim JY, Yoo CH, Yoon HJ, et al. Distribution of human norovirus in the coastal waters of South Korea. PLoS One 2016;11: e0163800.

9) Lee SG, Jheong WH, Suh Cl, Kim SH, Lee JB, Jeong YS, et al. Nationwide groundwater surveillance of noroviruses in South Korea, 2008. Appl Environ Microbiol 2011;77:1466-74.

10) Lee SG, Cho HG, Paik SY. Molecular epidemiology of norovirus in South Korea. BMB Rep 2015;48:61-7.

11) Lee $H$, Kim M, Lee JE, Lim M, Kim M, Kim JM, et al. Investigation of norovirus occurrence in groundwater in metropolitan Seoul, Korea. Sci Total Environ 2011;409:2078-84.

12) Lee BR, Lee SG, Park JH, Kim KY, Ryu SR, Rhee OJ, et al. Norovirus contamination levels in ground water treatment systems used for food-catering facilities in South Korea. Viruses 2013;5:1646-54.

13) Thompson JD, Higgins DG, Gibson TJ. Clustal W: improving the sensitivity of progressive multiple sequence alignment through sequence weighting, position-specific gap penalties and weight matrix choice. Nucleic Acids Res 1994;22: 4673-80

14) Saitou N, Nei M. The neighbor-joining method: a new method for reconstructing phylogenetic trees. Mol Biol Evol 1987:4:406-25.

15) Ho EC, Cheng PK, Lau AW, Wong AH, Lim WW. Atypical norovirus epidemic in Hong Kong during summer of 2006 caused by a new genogroup II/4 variant. J Clin Microbiol 2007;45:2205-11.

16) Kim SH, Cheon DS, Kim JH, Lee DH, Jheong WH, Heo YJ, et al. Outbreaks of gastroenteritis that occurred during school excursions in Korea were associated with several waterborne strains of norovirus. J Clin Microbiol 2005;43:4836-9.

17) Ham H, Oh S, Seung H, Jang J, Han $C$. Human norovirus genogroups detected from acute gastroenteritis patients in seoul from May 2013 to April 2015. J Bacteriol Virol 2015;45:376-81.

18) Lee JS, Joo IS, Ju SY, Jeong MH, Song YH, Kwak HS. Research on the contamination levels of norovirus in food facilities using groundwater in South Korea, 2015-2016. Int J Food Microbiol 2018;280:35-40. 